Gi respons på artikler gjennom artiklenes kommentarfelt på tidsskriftet.no.

Innleggene publiseres fortløpende på Tidsskriftets nettside og et utvalg

av innleggene publiseres også i papirutgaven i spalten «Brev til redaktøren».

Redaksjonen forbeholder seg retten til å foreta redaksjonelle endringer.

Forfattere av vitenskapelige artikler har tilsvarsrett, jf. Vancouver-gruppens regler.

\section{Re: En kvinne i 40-årene med kreft, synkope og kramper}

Denne kasuistikken beskriver alvorlige bivirkninger av alternativ behandling med cesium (1). Nasjonalt forskningssenter innen komplementær og alternativ medisin (NAFKAM) varslet den 27. november Helsedirektoratet om denne formen for alternativ behandling av kreft. Mer informasjon om saken finnes på Nifab.no, en statlig nettportal som tilbyr kunnskapsbasert informasjon om alternativ behandling (2).

\section{Vinjar Fønnebø}

Vinjar.Fonnebo@uit.no

Vinjar Fønnebø (f. 1952) er professor ved NAFKAM, UiT Norges arktiske universitet.

Ingen oppgitte interessekonflikter.

\section{Litteratur}

1. Warsame MO, Gamboa D, Nielsen EW. En kvinne i 40-årene med kreft, synkope og kramper. Tidsskr Nor Legeforen 2014; 134: 1855 - 7.

2. Nifab.no. Cesium - Farlig kreftbehandling på veg inn i Norge. 27.11.14. http://nifab.no/aktuelt/nifab/advarer_mot_farlig_kreftbehandling (12.12.2014).

\section{Re: Er det overvekt eller vektfokus som er helseskadelig?}

Samdal og Melands artikkel er tankevekkende (1). Når det viser seg at over halvparten av norske 40-50 åringer havner i kategorien overvekt, uten at det har sikre helsemessige konsekvenser, synes tiden absolutt å være inne for å revidere skalaen for overvekt.

Jeg har i alle år reagert på at personer med BMI > 30 karakteriseres som personer med fedme, eller fete, som det heter på godt norsk. Dette er et stigmatiserende uttrykk som etter min mening ikke hører hjemme i en offentlig klassifisering. Håper de ansvarlige for denne klassifiseringen snarest mulig finner alternativer. Jeg synes det må være bedre å bruke gradering av overvekt, for eksempel moderat overvekt og betydelig overvekt, eller lignende.

\section{Jon Storstein}

jstorstein@gmail.com

Jon Storstein (f. 1948) er spesialist i arbeidsmedisin og bedriftslege ved Stamina Helse.

Ingen oppgitte interessekonflikter

\section{Litteratur}

1. Samdal GB, Meland E. Er det overvekt eller vektfokus som er helseskadelig? Tidsskr Nor Legeforen 2014; 134: 2247-8.

\section{Re: Klimakamp er helsearbeid}

Gunnar Kvåle har i Tidsskriftet nr. 16/2014 en meget leseverdig kronikk vedrørende klimakamp (1). Uten å ta standpunkt til Kvåles beskrivelse av hvor ille verden kan bli, og hva som er årsaken(e), vil jeg bemerke at et av hovedproblemene, som er overbefolkning, kun blir nevnt i en bisetning. Vi er i dag ca.7 milliarder mennesker på denne kloden, og antallet vil øke med ca. 600 millioner hvert tiende år, dersom ikke noe dramatisk skjer (2).
Befolkningsøkningen vil medføre et krav om mer energi. Til nå er det kun enkeltpersoner, små grupper og mindre samfunn som arbeider for å senke levestandarden. Overalt ellers jobbes det for, loves og kreves økt levestandard. Også blant de som allerede har mer enn nok økonomisk og materielt (les oss); kanskje spesielt disse.

Befolkningsveksten må reduseres i alle deler av verden, både i rike og fattige land. For å oppnå dette, mener jeg det må jobbes på to hovedfronter:

1. Rettferdig fordeling av tilgjengelige materielle/økonomiske goder, noe som antakelig vil svi mest for de som har mye fra før. 2. Økt satsing på utdannelse/informasjon, spesielt i fattige land med mye analfabetisme, og spesielt rettet mot kvinnene, som jeg vil tro etter hvert, og kanskje heldigvis, vil overta verdensherredømmet.

Det er påfallende at homo sapiens, med sin velutviklede hjerne, ikke har innsett hvor store energimengder som finnes i «nærheten»: Vi bor på en klode der $50 \%$ av overflaten til enhver tid blir tilført store energimengder fra solen, og vi bor på en klode som bobler og koker innvendig med en kjernetemperatur på 5-6000 grader celsius. Dersom vi stikker følepinnen vår langt nok rett nedover, kan vi hente opp uante mengder geotermisk energi.

Det hjelper lite at Kari og Ola fra Oslo Vest sykler til jobben, når et stort og økende antall innbyggere benytter tilbudet om å fly OsloBarcelona for samme pris som en togtur Hamar/Gardermoen med honnørbillett.

\section{Knut Fjæstad}

knufjae@online.no

Knut Fjæstad (f. 1947) er overlege ved Sykehuset Innlandet Hamar, Kreftavdelingen.

Ingen oppgitte interessekonflikter.

\section{Litteratur}

1. Kvåle G. Klimakamp er helsearbeid. Tidsskr Nor Legeforen 2014; 134: 1582-4 2. Wikipedia. Verdens befolkning. http://no.wikipedia.org/wiki/Verdens_befolkning (28.11.2014)

\section{G. Kvåle svarer:}

Jeg vil takke Knut Fjæstad for kommentaren, og er enig i at det er naturlig å diskutere global befolkningsvekst blant årsakene til økende klimagassutslipp. Hovedproblemet er imidlertid at dagens befolkning på 7 milliarder står for et økende fossilbasert forbruk som alt nå forårsaker klimagassutslipp på et nivå kloden kan tåle bare i få år framover. For å oppnå en forsvarlig klimautvikling må dette endres lenge før en eventuell nedgang i fødselstall vil kunne få vesentlig betydning for utslippsveksten. I denne sammenheng er det grunn til å påpeke at en norsk firebarns middelklassefamilie står for klimagassutslipp som er rundt 10 ganger høyere enn en gjennomsnittsfamilie av samme størrelse i mange fattige land (1).

Førsteprioritet i klimakampen må derfor være at produksjon og bruk av kull, olje og gass raskt reduseres. Rundt 80 prosent av reservene som fossilindustrien planlegger å utvinne, må bli værende i grunnen om vi skal ha en rimelig sjanse for å unngå svært alvorlige klimaendringer (2). Det haster derfor med en atskillig sterkere regulering av fossilindustrien gjennom virkemidler som fører til mindre produksjon. Historien viser at ensidig fokus på utslippsreduksjoner ikke har ført fram. En «fornybarrevolusjon» er nødvendig slik at energi fra kull, olje og gass raskt blir erstattet av fornybare alternativer; sol, vind og vann. 